\title{
BATTERY RECYCLING BY HYDROMETALLURGY: EVALUATION OF SIMULTANEOUS TREATMENT OF SEVERAL CELL SYSTEMS
}

\author{
C.A. Nogueira ${ }^{1}$, F. Margarido ${ }^{2}$ \\ ${ }^{1}$ LNEG - Laboratório Nacional de Energia e Geologia, UPCS; \\ Estrada do Paço do Lumiar; 1649-038 Lisboa, Portugal; carlos.nogueira@lneg.pt \\ ${ }^{2}$ Instituto Superior Técnico, Technical University of Lisbon (TULisbon); \\ Av. Rovisco Pais; 1049-001 Lisboa, Portugal; fernanda.margarido@ist.utl.pt
}

Keywords: Battery recycling, Hydrometallurgy, Leaching, Solvent Extraction

\begin{abstract}
A research work has being carried out aiming at evaluating the possibility of treating simultaneously several electrochemical systems of spent batteries using the same process, in order to overcome the high costs and difficulties of selective collection and sorting. $\mathrm{Zn}-\mathrm{MnO}_{2}$ systems, representing more than $75 \%$ of portable battery market, shall be treated in dedicated processes. The treatment assessment using a single hydrometallurgical process of the other major systems ( $\mathrm{NiCd}$, $\mathrm{NiMH}$ and $\mathrm{Li}$-ion), having $\mathrm{Ni}$ and $\mathrm{Co}$ as main metals, was the aim of the research work here reported. Sulfuric acid leaching was demonstrated to be adequate for dissolving more than $90 \%$ of the metals of interest contained in batteries. The subsequent separation of metals by solvent extraction, using organophosphorous extractants like DEHPA and Cyanex 272, allowed the production of pure solutions of rare earths, cadmium/manganese, cobalt, nickel and lithium, enabling their further recovering.
\end{abstract}

\section{Introduction}

Recycling is the best approach for end-of-life management of spent batteries mainly by environmental reasons but also motivated by resources conservation and, in some cases, by economic profits. Most relevant electrochemical systems of portable cells are $\mathrm{Zn}-\mathrm{MnO}_{2}(\mathrm{ZMB}$, alkaline and saline), nickel-cadmium ( $\mathrm{NiCd}$ ), nickel-metal hydride $(\mathrm{NiMH})$ and lithium-ion (LIB). These batteries are collected, sorted and usually treated separately, applying for pyrometallurgical or hydrometallurgical technologies, the former being the most common.

Several processes have been developed and some of them industrially applied, as described in some available review papers [1, 2]. In Europe for ZMB systems the oldest processes are Batrec [3] and Citron [4]. Although having differences in details, both are based on pyrometallurgical recovery of zinc by distillation, in metallic or oxide forms, being manganese retained in the slag together with iron. Hydrometallurgical alternatives are also available, like Zincex [5] and Recupyl [6] processes, both using sulfuric acid solutions as leachant. The application of the existing technologies to battery recycling, instead of using dedicated processes, is other alternative already tested, being the Waeltz furnace or the Imperial Smelting some examples.

$\mathrm{NiCd}$ batteries are being recycled for many decades using pyrometallurgical treatment such as the SNAM-SAVAN, SAB-NIFE and INMETCO processes [2], where cadmium is volatilized and recovered to be used in the manufacturing of new battery electrodes. These companies also claim to treat NiMH batteries, but some important metals like nickel and rare earths are not truly 
valorized with these technologies. Some nickel smelters can also process these batteries for reclaiming nickel. For LIB's, some existing pyrometallurgical processes, namely cobalt smelters (e.g. Xstrata), can recover cobalt from this type of cells, but once again lithium an important and strategic metal, is lost in the slag. Recupyl claims a process for treating LIB's by hydrometallurgy where the most important metals are recoverable.

The usual approach for each battery type is dedicated processes but they require selective collection of batteries by cell system which is difficult, being sorting expensive. This is a drawback in overall economics of battery recycling. In order to contribute for overcoming such problem, a research work has being carried out aiming at evaluating the possibility of treating groups of batteries in the same process. Hydrometallurgy was the technology proposed due to versatility and possibility of attaining high metal separation yields and recoveries. The main characteristics of the process in development as well as the main achievements attained are here presented.

\section{Spent Battery Flows, Composition and Metals Balance}

Figure 1 shows the weight distribution of spent batteries in Portugal, according with data from Ecopilhas, a licensed spent battery management company. Data from other European countries are essentially similar. Primary batteries of $\mathrm{Zn}-\mathrm{MnO}_{2}$ systems (alkaline and saline) are still the more relevant accounting for about $80 \%$ of the market share. The saline type contributes only with near $15 \%$ and is continuously decreasing. The actual trend is to increase the usage of secondary batteries, mainly the Li-ion systems, and to decrease the primary battery consumption. The NiCd system is also declining, although data for the disappearance of "portable NiCd's", predicted some years ago, were not confirmed, and cadmium batteries are still the preferable for some small equipments such as cordless tools.

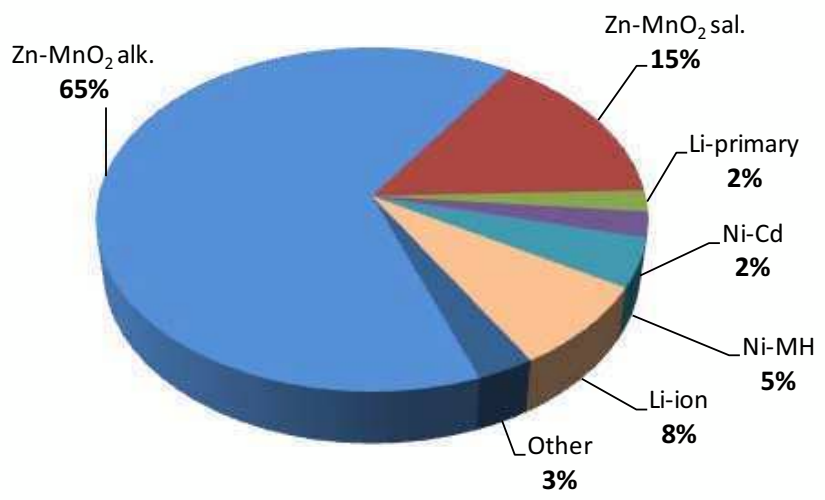

Figure 1. Market of spent portable batteries by electrochemical system (weight \%).

Typical elemental composition of spent batteries, as well as the main phases constituting the electrode materials is presented on Table I. For each cell system, only the main metals are considered. All batteries are high metal concentrates containing some valuable metals (e.g Ni, $\mathrm{Co}, \mathrm{RE}$ ), so the economic benefits of treating these residues are surely one of the factors to be considered on the management equation. Electrodes are manufactured by compressed powders forming plaques or rolls, being essentially composed by oxides or hydrated oxides, but some metallic phases such as $\mathrm{Ni}^{\mathrm{o}}$ (used as support and conductor in Ni-based batteries, in powder or 
fine mesh form) and rare-earth-Ni alloys are also found. Besides electrodes, there are other battery components such as external cases, polymeric separators and electrolytes. Iron as a steel alloy, usually plated with nickel, is present in external cases of almost batteries types. Graphite powder is a conductor widely used in some batteries. Other materials like metal connectors (steel, copper and other metals and alloys) and copper/aluminium foils used as electrode supports in Li-ion batteries are found. Electrolytes are impregnated in porous polymer sheets between the electrodes. Most used ionic conductors are inorganic, such as $\mathrm{KOH}$ (in alkaline, NiCd and $\mathrm{NiMH}$ ) or salts like $\mathrm{NH}_{4} \mathrm{Cl} / \mathrm{ZnCl}_{2}$ (in saline), but salts in organic solvents, e.g. $\mathrm{LiPF}_{6}$ in dimethylcarbonate, are also utilized in lithium batteries. Small plastic components are also found inside the batteries as insulating materials, or in the exterior as battery labels.

Table I. Typical elemental composition and electrode phases of spent batteries.

\begin{tabular}{|c|c|c|c|c|c|}
\hline \multirow[b]{2}{*}{ Element } & \multicolumn{5}{|c|}{ Elemental composition (wt $\%$ ) of batteries } \\
\hline & $\begin{array}{l}\mathrm{Zn}-\mathrm{MnO}_{2} \\
\text { (alkaline) }\end{array}$ & $\begin{array}{c}\mathrm{Zn}-\mathrm{MnO}_{2} \\
\text { (saline) }\end{array}$ & $\mathrm{NiCd}$ & NiMH & Li-ion \\
\hline $\mathrm{Zn}$ & 20 & 23 & - & - & - \\
\hline $\mathrm{Mn}$ & 28 & 22 & - & 1.9 & - \\
\hline $\mathrm{Fe}$ & 23 & 20 & 40 & 25 & 40 \\
\hline $\mathrm{Ni}$ & - & - & 20 & 33 & - \\
\hline $\mathrm{Cd}$ & - & - & 15 & - & - \\
\hline Co & - & - & 1 & 4 & 20 \\
\hline RE & - & - & - & 10 & - \\
\hline $\mathrm{Li}$ & - & - & - & - & 3 \\
\hline $\begin{array}{l}\text { Main } \\
\text { phases in } \\
\text { electrodes }\end{array}$ & $\begin{array}{c}\mathrm{ZnO}, \\
\mathrm{ZnOMn}_{2} \mathrm{O}_{3}, \\
\mathrm{Mn}_{3} \mathrm{O}_{4}, \\
\mathrm{MnO}_{2}, \\
\text { graphite }\end{array}$ & $\begin{array}{l}\text { The same as } \\
\text { alkaline but } \\
\text { also } \\
\mathrm{Zn}_{5}(\mathrm{OH})_{8} \mathrm{Cl}_{2} \cdot \mathrm{H}_{2} \mathrm{O}\end{array}$ & $\begin{array}{c}\mathrm{Cd}(\mathrm{OH})_{2}, \\
\gamma-\mathrm{Cd}(\mathrm{OH})_{2}, \\
\mathrm{Ni}(\mathrm{OH})_{2}, \\
\mathrm{Ni}^{\mathbf{0}}\end{array}$ & $\begin{array}{c}(\mathrm{RE}) \mathrm{Ni}_{5}, \\
\mathrm{Ni}(\mathrm{OH})_{2}, \\
\mathrm{Ni}^{\mathrm{o}}\end{array}$ & $\begin{array}{l}\mathrm{Li}_{\mathrm{x}} \mathrm{C} \\
\mathrm{LiCoO} \text {, } \\
\text { graphite }\end{array}$ \\
\hline
\end{tabular}

Since $\mathrm{Zn}-\mathrm{Mn}$ batteries represent about $80 \%$ of the market share, when considering the treatment of all batteries in the same process, all the other batteries will suffer a dilution effect, which is an important aspect, because the same effect applies to valuable metals like cobalt, nickel, rare earths and lithium.

Table II illustrates this finding, where the predicted aqueous solutions composition of a hydrometallurgical processing of mixed batteries is presented, considering two scenarios: (I) simultaneous processing of all batteries; (II) processing two flows: $\mathrm{ZnMn}$ and $\mathrm{NiCo}$, the former containing the $\mathrm{Zn}-\mathrm{MnO}_{2}$ batteries and the latter containing the remaining systems rich in cobalt and nickel. When comparing the concentrations of metals such as cobalt, rare earths and lithium, using both scenarios, the dilution effect referred is clearly evidenced, being respectively 1.9, 0.47 and $0.31 \mathrm{~g} / \mathrm{L}$ for scenario (I) and $12,3.1$ and $1.6 \mathrm{~g} / \mathrm{L}$ for scenario (II), i.e. more than five times higher. This is very important considering technical and economic issues in metals recovery efficiency. 
Table II. Estimated leach liquor concentrations for the hydrometallurgical treatment of mixed batteries, considering two scenarios and leaching efficiencies above $90 \%$, at $\mathrm{L} / \mathrm{S}=10 \mathrm{~L} / \mathrm{kg}$.

\begin{tabular}{lcccccccc}
\hline \multirow{2}{*}{ Scenarios } & \multicolumn{6}{c}{ Metal concentrations in leach solutions (g/L) } \\
\cline { 3 - 9 } & & $\mathrm{Zn}$ & $\mathrm{Mn}$ & $\mathrm{Ni}$ & $\mathrm{Cd}$ & $\mathrm{Co}$ & $\mathrm{RE}$ & $\mathrm{Li}$ \\
\hline (I) All mixed & 17 & 23 & 2.1 & 0.37 & 1.9 & 0.47 & 0.31 \\
\hline (II) Two battery flows & a) ZnMn & 20 & 27 & - & - & - & - & - \\
& b) NiCo & - & 0.58 & 13 & 2.4 & 12 & 3.1 & 1.6 \\
\hline
\end{tabular}

\section{Experimental Development and Results Achieved}

\section{The BATMIX Process}

The BATMIX process (Figure 2) is a technological approach using a single technology for the recycling of the main portable batteries of the market. The $\mathrm{Zn}-\mathrm{MnO}_{2}$ systems are treated separately by a process consisting of comminution, leaching, solvent extraction and $\mathrm{Zn} / \mathrm{Mn}$ recovery [7]. Manganese in $\mathrm{MnO}_{2}$ form is leached by a reductive process using the own ferrous scrap of batteries as reducing agent [8]. After purification by iron removal and cementation with zinc powder, zinc is extracted and separated from manganese by an organic solvent, being both recovered as metals or crystallized salts.

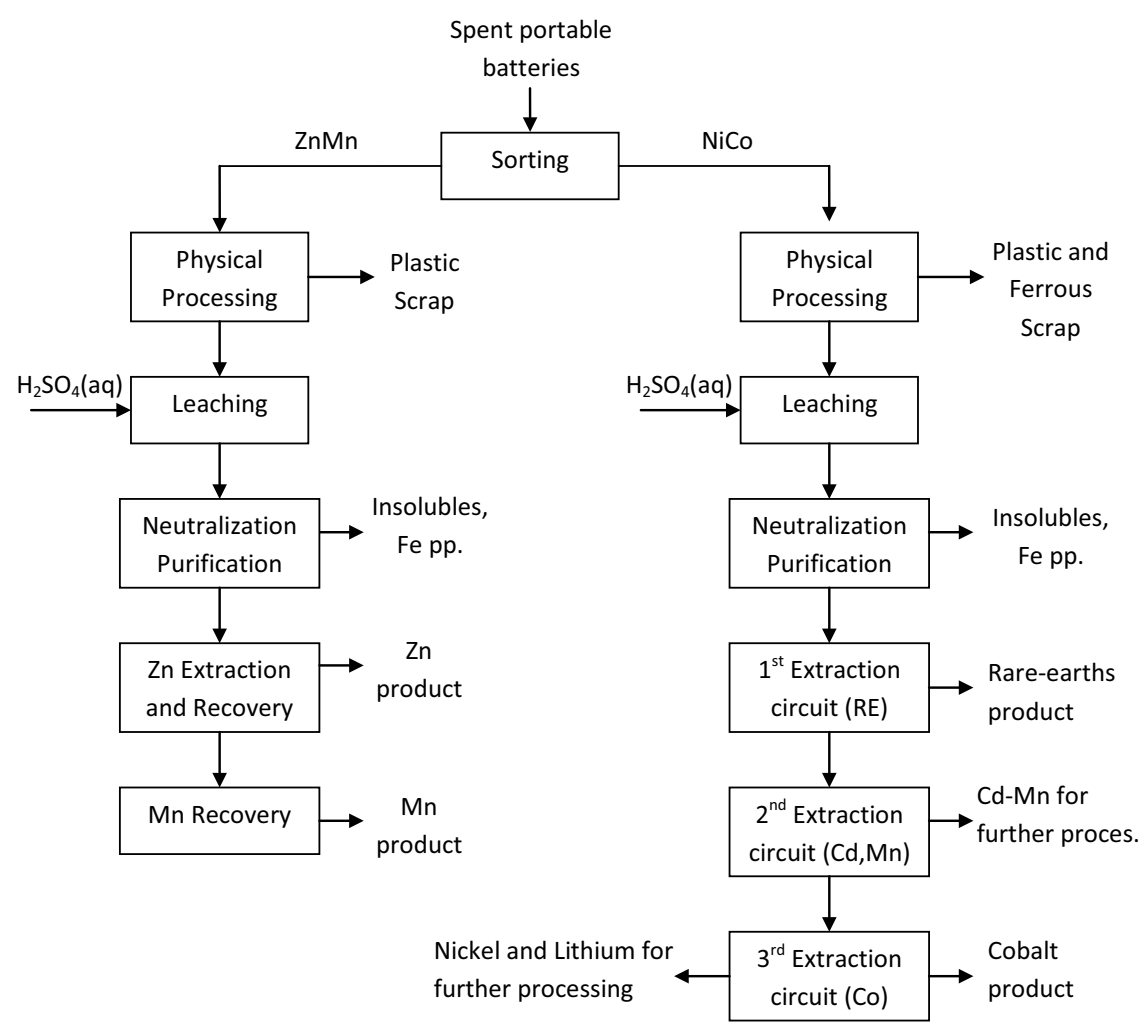

Figure 2. Flowsheet of the BATMIX Process. 
The remaining flow (NiCo), containing the nickel-cobalt-rich secondary batteries ( $\mathrm{NiCd}, \mathrm{NiMH}$ and $\mathrm{Li}$-ion), is treated together in other circuit. After the physical processing, the rich electrode fraction is leached with a $\mathrm{H}_{2} \mathrm{SO}_{4}$ solution and after purification metals are separated in three solvent extraction circuits (the first for rare-earths, the second for Cd-Mn and the third for cobalt) leaving nickel and lithium in the final raffinate for further processing.

Results hereafter presented summarize the experimental development of the process, mainly focused in the chemical operations, for simultaneous treatment of the three types of secondary batteries above referred.

\section{Physical Processing and Leaching}

The processing of the NiCo flow (with NiCd, NiMH and Li-ion batteries) starts with shredding using cutting or hammer mills followed by separation of scrap (ferrous and polymeric fractions). Sieving operation can allow good separation efficiency since scrap appears as large fragments while electrodes are disaggregated and recovered as fine particles. To improve the separation of electrode aggregates stick in scrap fragments, a washing operation can be used, simultaneously removing salts and electrolytes from solids. Magnetic separation is an alternative for removal steel scrap, but nickel in the metallic form would be also removed as well as other electrode particles finely attached, the reason why it is preferable the sieving. Other components present in coarse fraction are copper and aluminum foils used as electrode support of LIB's. Some unattached electrode can also be lost within these foils.

The sulfuric acid leaching involves the reaction and dissolution of several metal-bearing phases, with variable reactivity. However, most of the phases present in electrode materials are very reactive in acid media, thus the hydrometallurgical approach proposed seems appropriate. Figure 3 shows the leaching efficiency of some selected metals in NiMH and LIB. The rare-earth alloy $(\mathrm{La}, \mathrm{Ce}) \mathrm{Ni}_{5}$ is very reactive even with relatively low levels of leaching factors such as temperature and acid concentration $\left(50^{\circ} \mathrm{C}\right.$ and $\left.0.5 \mathrm{M} \mathrm{H}_{2} \mathrm{SO}_{4}\right)$, as the leaching yields attained for rare-earths demonstrate (Figure 3a). Nickel dissolved from this alloy is accounted for the $65 \%$ of nickel easily solubilized. The other portion of the solubilized $\mathrm{Ni}$ is due to nickel in hydroxide form which is also very reactive. After $2 \mathrm{~h}$ of reaction, both RE and Ni yields attain constant values. The remaining $\mathrm{Ni}$ fraction (near $35 \%$ ) is in metallic form (zero-valence, $\mathrm{Ni}^{\circ}$ ), which is less reactive and requiring higher levels of temperature and acidity to be leached. The same phases present in $\mathrm{NiCd}$ batteries, namely $\mathrm{Ni}(\mathrm{OH})_{2}$ and $\mathrm{Ni}^{\circ}$, present similar behavior, while anodic material of NiCd's composed by $\mathrm{Cd}(\mathrm{OH})_{2}$ is also very reactive.

As metals in LIB's are less reactive, the leaching at low temperatures is less effective. Figure $3 b$ shows the leaching yields obtained using the same acid concentration $(0.5 \mathrm{M})$ but at temperature of $90^{\circ} \mathrm{C}$. For the phase $\mathrm{LiCoO}_{2}$, the reaction proceeds until $2 \mathrm{~h}$ where complete leaching of $\mathrm{Co}$ and $\mathrm{Li}$ was achieved. In spite of being constituents of the same phase, lithium and cobalt leaching rates are not equal, being the solubilization of lithium faster. It is also represented the leaching of copper (not removed in physical steps), being its dissolution slower.

The remaining iron of the electrode fraction after physical separation is a contaminant in the leachates since part can be solubilized, although the maximum yields attained where only $20 \%$ (Figure 3). Even being present at low concentration level when compared with the major metals, iron shall be removed from solution after leaching, by precipitation in the form of jarosite or goethite. Acid used in leaching operation is close to stoichiometric values and so final solutions 
have the right conditions to precipitate iron $(\mathrm{pH} \sim 1.5-2.5)$ with minimum neutralization requirement. This demonstrates that using low acid concentration is possible to extract high levels of interested metals $(\mathrm{Ni}, \mathrm{Co}, \mathrm{RE}, \mathrm{Li})$ with minimum iron contamination.
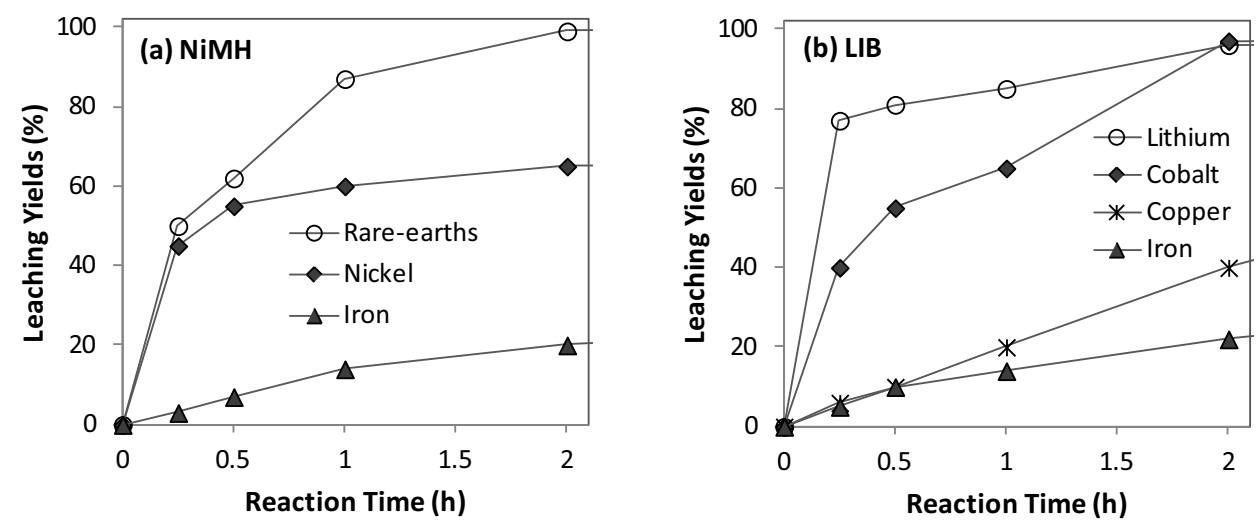

Figure 3. Leaching yields of selected metals in spent (a) NIMH, or (b) Li-ion batteries, as a function of time, using the conditions: $0.5 \mathrm{M} \mathrm{H}_{2} \mathrm{SO}_{4}, \mathrm{~L} / \mathrm{S}=20 \mathrm{~L} / \mathrm{kg}$ and $\mathrm{T}=50^{\circ} \mathrm{C}(\mathrm{a}), 90^{\circ} \mathrm{C} \mathrm{(b)}$.

\section{$\underline{\text { Separation Circuits by Solvent Extraction }}$}

The hydrometallurgical treatment of the leach liquor envisaging the separation and recovery of metal fractions is carried out using solvent extraction technology, with organophosphorous extractants. The following extraction order was found in batch lab testing, $\mathrm{RE}>\mathrm{Mn}, \mathrm{Cd}>\mathrm{Co}>\mathrm{Ni}>\mathrm{Li}$, which was the starting point for all further research. The process was developed in three multistage countercurrent circuits (Figure 4): (1) extraction of rare-earths; (2) extraction of a mixture of $\mathrm{Cd}$ and $\mathrm{Mn}$; (3) extraction of cobalt. The process was optimized in order to achieve high separation efficiencies and to generate high concentrated liquors to allow recovery of metals with minimum costs. The separation was assessed by choosing adequate extractants but essentially with a precise control of parameters like $\mathrm{pH}$ and organic/aqueous phase ratios. Results here presented correspond to a first step of the development, involving a minimal configuration (only 3-4 stages in extraction operations). So efficiencies and purities are still able to be increased in further optimization.

In the first circuit the extraction of rare-earths (mainly lanthanum) is accomplished by $1 \mathrm{M}$ DEHPA. The extraction proceeds without $\mathrm{pH}$ control in stages and so the extraction efficiency was only $97 \%$. A small $\mathrm{pH}$ adjustment in the last stage will be enough to increase the extraction of rare-earths, and a new proposal is being prepared to achieve $99 \%$ minimum recovery. A final strip liquor containing $43 \mathrm{~g} / \mathrm{L}$ RE with $99.7 \%$ purity is expected to be generated from which a rare-earth commodity can be produced. In the second circuit, occurs the extraction of manganese and cadmium, since their separation with these extractants was shown to be very difficult. In this case, the extractant 0.5M DEHPA was utilized, producing a final liquor with $59 \mathrm{~g} / \mathrm{L} \mathrm{Cd}$ and 13 $\mathrm{g} / \mathrm{L} \mathrm{Mn}$, corresponding to an overall extraction of $99 \%$ for both metals. This solution shall be treated by chemical methods to separate the metals (e.g. by oxidation and precipitation of $\mathrm{MnO}_{2}$ ). Note that the manganese in this process comes from the anode materials of NiMH cells, where $\mathrm{Mn}$ is a common substitute used in the alloy composition and can vary substantially from cell to cell. Another important point is related with the high concentration of RE $(1.9 \mathrm{~g} / \mathrm{L})$ in this 
Cd-Mn stream, due to unextracted lanthanides in the first circuit. The third circuit refers to cobalt separation from nickel, using 1M Cyanex 272. A very good separation can be achieved, the final strip liquor containing $124 \mathrm{~g} / \mathrm{L}$ Co with $99.8 \%$ purity, near to the cobalt sulfate solubility point. The recovery efficiency for cobalt is $99.9 \%$. The other output stream at the end of the process, the final raffinate, contains more than $99.9 \%$ of the nickel. This solution also contains all the lithium, and further separation of these two metals in now being investigated.

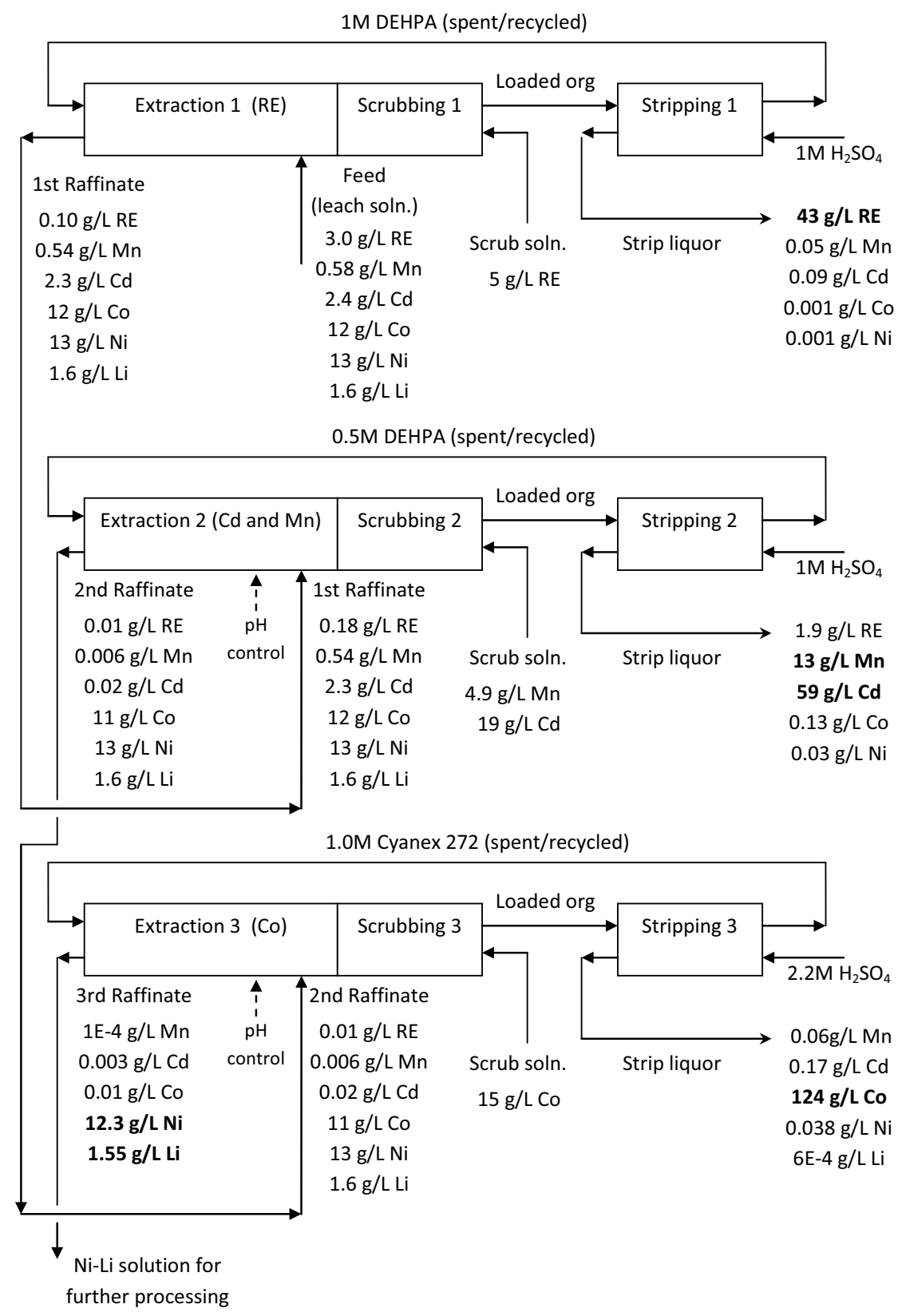

Figure 4. Flowsheet of the separation process by solvent extraction. 


\section{Conclusions}

A hydrometallurgical process for the treatment of mixed flows of spent portable batteries was developed, based on physical processing, sulfuric acid leaching and solvent extraction. The treatment of $\mathrm{Zn}-\mathrm{MnO}_{2}$ shall be done separately, and the remaining flow containing the $\mathrm{NiCd}$, $\mathrm{NiMH}$ and Li-ion cells is processed together. The leaching with diluted sulfuric acid solutions allows attaining high leaching efficiency of all metallic phases, except $\mathrm{Ni}$ in the zero-valence form which requires higher concentration and temperature to solubilize efficiently. The metals separation from the leachate is based on three solvent extraction circuits, from which three pure and concentrated streams are produced, the first one with rare-earths, the second one with a mixture of cadmium and manganese and the third one with cobalt. Nickel and lithium remain in the final rafinatte. Complementary treatment of streams with more than one metal (namely $\mathrm{Cd}+\mathrm{Mn}$ and $\mathrm{Ni}+\mathrm{Li}$ ) is still necessary to recover all the elements individually.

\section{References}

1. D.C.R. Espinosa, A.M. Bernardes and J.A.S. Tenório, "An overview on the current processes for the recycling of batteries", J. Power Sources, 135 (2004), 311-319.

2. E. Sayilgan, T. Kukrer, G. Civelekoglu, F. Ferella, A. Akcil, F. Veglio and M. Kitis, "A review of technologies for the recovery of metals from spent alkaline and zinc-carbon batteries", Hydrometallurgy, 97 (2009), 158-166.

3. M. Beck, "Batrec: recovering metals", Recycling International, May,4 (2004), 24-27.

4. K. Vollrath, "Battery recycling in Europe: confusion and high costs", Recycling International, Nov, 7 (1999), 18-23.

5. C. Frías, D. Martín, G. Díaz, J. Falgueras and V. Baylina, "Highlights of domestic battery recycling plant based on the modified Zincex process sfter five years successful operation", REWAS 2004 - Global Symp. on Recycling, Waste Treatment and Clean Technology, Vol III, Madrid, Spain, 26-29 Sept., ed. I. Gaballah, B. Mishra, R. Solcjzahal and M. Tifnaka, (Warredale, USA and S. Sebastián, Spain: TMS and Inasmet, 2004), 2299-2308

6. F. Tedjar, "Recycling used electric cells by hydrometallurgical treatment", Int. Patent Appl., WO 021708 A3, 13 March (2003).

7. R.N.G. Guerra, F. Pedrosa, F. Margarido and C.A. Nogueira, "Metals recovery from spent Zn$\mathrm{MnO} 2$ batteries by Hydrometallurgy", REWAS 2008 - Global Symp. on Recycling, Waste Treatment and Clean Technology, Cancun, Mexico, 12-15 Oct., ed. B. Mishra, C. Ludwig and S. Das, (Warredale, USA: TMS, 2008), 1039-1044.

8. F. Pedrosa, J.P. Feu, Marta Cabral, C.A. Nogueira and F. Margarido, "Integration of physical operations in the hydrometallurgical processing of spent $\mathrm{Zn}-\mathrm{MnO}_{2}$ batteries", EBR'09 Electronics \& Battery Recycling '09 (Proc. of 2nd Intern. Conf.), 24-26 June, Toronto, (Birrwil, Switzerland: ICM AG, 2009) 


\title{
Energy Technology 2012: Carbon Dioxide Management and Other Technologies
}

\author{
Proceedings of symposia sponsored by \\ the Energy Committee of \\ the Extraction and Processing Division and \\ the Light Metals Division of \\ TMS (The Minerals, Metals \& Materials Society) \\ Held during the \\ TMS 2012 Annual Meeting \& Exhibition \\ Orlando, Florida, USA \\ March 11-15, 2012
}

Edited by

Maria D. Salazar-Villalpando

Neale $R$ Neelameggham

Donna Post Guillen

Soobhankar Pati

Gregory K. Krumdick

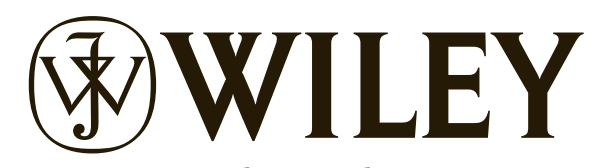

A John Wiley \& Sons, Inc., Publication 


\title{
Copyright (C) 2012 by The Minerals, Metals, \& Materials Society. All rights reserved.
}

\author{
Published by John Wiley \& Sons, Inc., Hoboken, New Jersey. \\ Published simultaneously in Canada.
}

No part of this publication may be reproduced, stored in a retrieval system, or transmitted in any form or by any means, electronic, mechanical, photocopying, recording, scanning, or otherwise, except as permitted under Section 107 or 108 of the 1976 United States Copyright Act, without either the prior written permission of The Minerals, Metals, \& Materials Society, or authorization through payment of the appropriate per-copy fee to the Copyright Clearance Center, Inc., 222 Rosewood Drive, Danvers, MA 01923, (978) 750-8400, fax (978) 750-4470, or on the web at www.copyright.com. Requests to the Publisher for permission should be addressed to the Permissions Department, John Wiley \& Sons, Inc., 111 River Street, Hoboken, NJ 07030, (201) 748-6011, fax (201) 748-6008, or online at http:// www.wiley.com/go/permission.

Limit of Liability/Disclaimer of Warranty: While the publisher and author have used their best efforts in preparing this book, they make no representations or warranties with respect to the accuracy or completeness of the contents of this book and specifically disclaim any implied warranties of merchantability or fitness for a particular purpose. No warranty may be created or extended by sales representatives or written sales materials. The advice and strategies contained herein may not be suitable for your situation. You should consult with a professional where appropriate. Neither the publisher nor author shall be liable for any loss of profit or any other commercial damages, including but not limited to special, incidental, consequential, or other damages.

Wiley also publishes books in a variety of electronic formats. Some content that appears in print may not be available in electronic formats. For more information about Wiley products, visit the web site at www.wiley.com. For general information on other Wiley products and services or for technical support, please contact the Wiley Customer Care Department within the United States at (800) 762-2974, outside the United States at (317) 572-3993 or fax (317) 572-4002.

Library of Congress Cataloging-in-Publication Data is available.

ISBN 978-1-11829-138-2

Printed in the United States of America.

10987654321

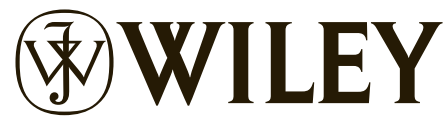

TMMS

A John Wiley \& Sons, Inc., Publication 